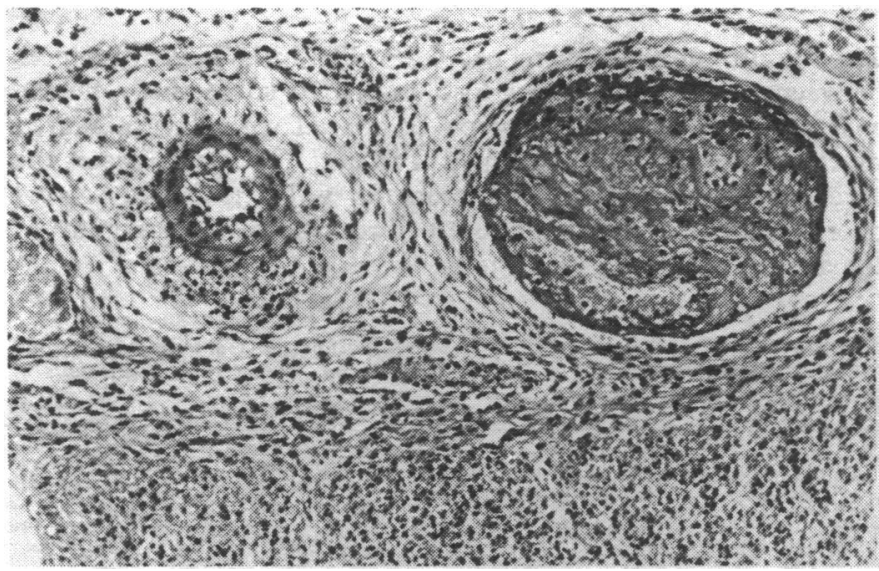

FIG. 6-Submucosal venous thrombosis with a mild infiammatory reaction. (H. \& E. $\times$ 87.)

well, though the onset of necrotizing enterocolitis followed more rapidly than in most cases. It is probable that exchange transfusion in association with infection were combined aetiological factors.

Although all diagnoses were confirmed radiologically and histologically, the cases form a homogeneous clinical group in which the antecedent history of prematurity and gastroenteritis and more specifically salmonella infection, progressing to the acute abdominal catastrophe, was so typical that there was no difficulty in making a firm diagnosis on clinical grounds.
Though necrotizing enterocolitis in premature babies remains a disease of multifactorial origin, this series lends strong support to the aetiological significance of infection.

We wish to thank Professor S. Wayburne and members of the Paediatric Staff for access to cases; the Superintendent of Baragwanath Hospital for permission to publish; the Director of the South African Institute for Medical Research for facilities granted; and Mr. M. Ulrich for photomicrographs.

\section{References}

Beck, J. M., Dinner, M., and Chappel, J. (1971). South African fournal of Surgery, 9, 39.

Berdon, W. E., et al. (1964). Radiology, 83, 879.

Blanc, W. A. (1952). Clinical Obstetrics and Gynecology, 2, 705.

British Medical Fournal, 1970, 3, 121.

Castor, W. R. (1968). Canadian Medical Association fournal, 99, 934

Corkery, J. J., Dubowitz, V., Lister, J., and Moosa, A. (1968). British Medical fournal, 4,345

Fetterman, G. H. (1971). Pediatrics, 48, 345.

Hermann, R. E. (1965). Surgery, 58, 436.

Lloyd, J. R. (1969). Fournal of Pediatric Surgery, 4, 77.

Mizrahi, A., Barlow, O., Berdon, W., Blanc, W. A., and Silverman, W. A. (1965). Journal of Pediatrics, 66, 697.

Orme, R. L., and Eades, S. M. (1968). British Medical fournal, 4, 349.

Rossier, A., Sarrut, S., and Delplanque, J. (1959). Semaine des Hopitaux Paris, 35, 1428.

Stevenson, J. K., Graham, C. B., Oliver, T. K., and Goldenberg, V. E. (1969). American fournal of Surgery, 118, 260.

Touloukian, R. J., Berdon, W. E., Amoury, R. A., and Santulli, T. V. (1967) fournal of Pediatric Surgery, 2, 389.

Waldhausen, J. A., Herendeen, T., and King, H. (1963). Surgery, 54, 365. Willi, H. von (1944). Annales de Pédiatrie, 162, 87.

Wilson, S. E., and Woolley, M. M. (1969). Archives of Surgery, 99, 563.

\title{
Comparison of Subjective Estimates by Surgeons and Anaesthetists of Operative Blood Loss
}

\author{
A. E. DELILKAN
}

British Medical fournal, 1972, 2, 619-621

\section{Summary}

Altogether 100 cases were studied to compare the subjective estimates of operative blood loss by anaesthetists (six in number) and by surgeons (22 in number). Their estimates were compared with the blood loss measured by a colorimetric method, which was assumed to be the operative blood loss. The results showed that surgeons are less reliable judges of operative blood loss then anaesthetists. When objective measurement of operative blood loss is impracticable the anaesthetist and the surgeon should jointly make a subjective estimation.

\section{Introduction}

Operative blood loss can be estimated subjectively (by the anaesthetist or the surgeon), but this method is universally accepted as unreliable. There are many objective methods such as the gravimetric method (Wangensteen, 1942), various colorimetric methods (Gatch and Little, 1924; Endahl and

\footnotetext{
Department of Anaesthesiology, University of Malaya, Kuala Lumpur, Malaysia

A. E. DELILKAN, M.B., B.S., F.F.A. R.C.S., Senior Lecturer
}

Moller, 1952; Rustard, 1963), the electric conductivity method (LeVeen and Rubricius, 1958), and isotopic direct methods with the Volemetron (Williams and Fine, 1961). Even the objective methods have an error in estimation but this is usually significantly less than that of the subjective methods and thus more acceptable clinically.

In most hospitals in this part of the world it is often not possible to use the more sophisticated objective methods for estimating operative blood loss routinely for two reasonsfirstly, because such facilities do not exist and, secondly, because operative schedules are usually pressed for time. The operative blood loss is thus measured either by the gravimetric method or by some colorimetric method (where facilities exist) only in the more major cases where a large blood loss is expected. In most other situations the subjective estimation is used. This sometimes leads to a difference of views between the surgeon and the anaesthetist.

The purpose of this paper is to try to evaluate which of the two, the surgeon or the anaesthetist, is the more unreliable in estimating operative blood loss, a colorimetric method being used as the constant for comparison.

\section{Patients and Method}

Altogether 100 cases were studied during July to December 1969 at the University Hospital, Kuala Lumpur. The patients (51 males, 49 females) were aged 10-87 (mean 43.9) years and 
weighed $26-86.4$ (mean 50.2 ) $\mathrm{kg}$. There were 88 elective operations and 12 emergency operations. The surgical disciplines, concerned in the operations are shown in Table I.

TABLE I-Distribution of Cases According to Surgical Department Involved

\begin{tabular}{|c|c|c|c|c|c|}
\hline \multicolumn{3}{|c|}{ Surgical Department } & \multirow{2}{*}{$\begin{array}{c}\begin{array}{c}\text { No. of } \\
\text { Elective } \\
\text { Cases }\end{array} \\
66 \\
12 \\
10\end{array}$} & \multirow{2}{*}{$\begin{array}{c}\begin{array}{c}\text { No. of } \\
\text { Emergency } \\
\text { Cases }\end{array} \\
3 \\
6 \\
3\end{array}$} & \multirow{2}{*}{$\begin{array}{c}\text { Total } \\
69 \\
18 \\
13\end{array}$} \\
\hline $\begin{array}{l}\text { General surgery } \\
\text { Obstetrics and gynaecology } \\
\text { Orthopaedic surgery ... }\end{array}$ & $\begin{array}{l}\ldots \\
\because \\
\cdots\end{array}$ & $\begin{array}{l}. \\
\because \\
\cdots\end{array}$ & & & \\
\hline Total. . & $\cdots$ & .. & 88 & 12 & 100 \\
\hline
\end{tabular}

The 22 surgeons (all with a postgraduate degree) who took part in this study had 4-18 years' experience in their fields, and the six anaesthetists (all with postgraduate qualifications) 3-14 years.

Choice of patients was random except that operations which lasted less then 30 minutes were not included. At the end of every operation studied the anaesthetist asked the surgeon for his estimate of the blood lost during the operation and noted the figure in millilitres on a form, inserting his own estimate by the side. During the operation all swabs, sponges, etc. coming into contact with blood were put into a machine (a Perometer, AB Lars Ljungberg \& Co., Sweden) which measured the blood content by the colorimetric method. At the end of the operations the drapes stained with blood and the suction bottles containing blood etc. were also put or emptied into the Perometer and the total blood lost during the operation was thus estimated by the machine. The anaesthetic nurse was independently in charge of deriving the operative blood loss reading from the machine, and this volume was noted on the form bearing the estimates of the surgeon and anaesthetist. The forms were collected and kept by the anaesthetic nursing sister until 100 cases were completed. The 100 cases were then analysed.

The Perometer has a washing machine within. All swabs, compresses, and aspirated blood are put into a tank containing a known volume of water (39 1.) and a haemolysing agent. The blood is washed out and mixed with the liquid by an agitator and haemolysed to oxyhaemoglobin. The solution is circulated continuously from the tank via a filter through the measuring cell of a photometer which registers the solution's haemoglobin content. The measuring cell is set to allow for the patient's preoperative haemoglobin value, enabling the photometer to register direct the quantity of blood lost by the patient. The photometer responds only to light with the wavelength produced by haemoglobin, and the Perometer's accuracy is therefore not affected by the presence in the solution of other liquids. There is a low range $(0-600 \mathrm{ml})$ and a high range $(0-51$.$) . The measuring$ error is claimed by the manufacturers to be less than $\pm 3 \%$ on either range scale. Two such machines were used in this study. They were checked for accuracy after 50 cases and after completion of the 100 cases by using known volumes of blood (the blood bank supplied blood of more than 21 days' storage) as the "blood loss." The measuring error was $\pm 5 \%$.

These 100 cases were also studied to compare the surgeon's and anaesthetist's estimates of operative time to provide the data for a separate paper. The anaesthetist transfused blood if in his assessment it was required without any knowledge of the progressive blood loss measured by the Perometer in 98 cases. In the remaining two cases it was felt that without knowing the measured blood loss readings intermittently blood replacement might not be adequate, resulting in danger to life, and thus the study was abandoned in these two cases.

The Perometer was used as the common standard against which the subjective estimates of the anaesthetist and the surgeon could be referred for comparison purposes.

\section{Results}

The results obtained were based on 98 cases. The differences between the blood volumes lost, estimated subjectively by the anaesthetist and by the surgeon compared with that measured by the Perometer, are shown in Table II. For comparison the objective estimation by the Perometer is taken as the "actual operative blood loss" as opposed to the subjective estimates of the anaesthetist and the surgeon.

TABLE II-Difference Between Perometer Estimation (for Comparison Purposes taken as "Actual Operative Blood Loss") and Subjective Estimations of Anaesthetist and Surgeon

\begin{tabular}{|c|c|c|c|c|c|c|c|}
\hline \multicolumn{6}{|c|}{$\begin{array}{l}\text { Difference in Blood Loss in ml (Over- } \\
\text { estimation or Underestimation) }\end{array}$} & $\begin{array}{c}\begin{array}{c}\text { No. of Cases } \\
\text { Involving } \\
\text { Anaesthetists }\end{array} \\
55\end{array}$ & $\begin{array}{c}\begin{array}{c}\text { No. of Cases } \\
\text { Involving } \\
\text { Surgeons }\end{array} \\
32 \\
34\end{array}$ \\
\hline $\begin{array}{c}0-99 \\
100-199 \\
200-299 \\
300-399 \\
400-499 \\
500-599 \\
600-699 \\
700-799 \\
800-899 \\
900-999 \\
1,000-2,099\end{array}$ & $\begin{array}{l}\ldots \\
\ldots \\
\ldots \\
\cdots \\
\cdots \\
\cdots \\
\cdots\end{array}$ & $\begin{array}{l}\ldots \\
\because \\
\because \\
\cdots \\
\cdots \\
\cdots \\
\because \\
\cdots\end{array}$ & $\begin{array}{l}\ldots \\
\ldots \\
\cdots \\
\cdots \\
\cdots \\
\cdots \\
\cdots\end{array}$ & $\begin{array}{l}\ldots \\
\therefore \\
\therefore \\
\therefore \\
\therefore \\
\therefore \\
\therefore\end{array}$ & $\begin{array}{l}. \\
\because \\
\because \\
\because \\
\because \\
\because \\
\because \\
.\end{array}$ & $\begin{array}{r}55 \\
25 \\
6 \\
4 \\
4 \\
3 \\
1 \\
= \\
= \\
-\end{array}$ & $\begin{array}{r}32 \\
24 \\
12 \\
7 \\
10 \\
4 \\
4 \\
1 \\
1 \\
3\end{array}$ \\
\hline Total & $\cdots$ & $\cdots$ & $\ldots$ & .. & . & 98 & 98 \\
\hline
\end{tabular}

Mean difference between actual blood loss (Perometer) and anaesthetist's estimate $137.8 \mathrm{ml}$ (S.D. $\pm 138 \mathrm{ml}$ )

Mean difference between actual blood loss (Perometer) and surgeon's estimate $267.3 \mathrm{ml}$ (S.D. $\pm 298 \mathrm{ml}$ ).

The difference between the two means $129.5 \mathrm{ml}$ (S.E. $\pm 33.2 \mathrm{ml}$ ).

The difference between the two means is about four times the standard error; this difference is highly significant statistically $(P<0.01)$.

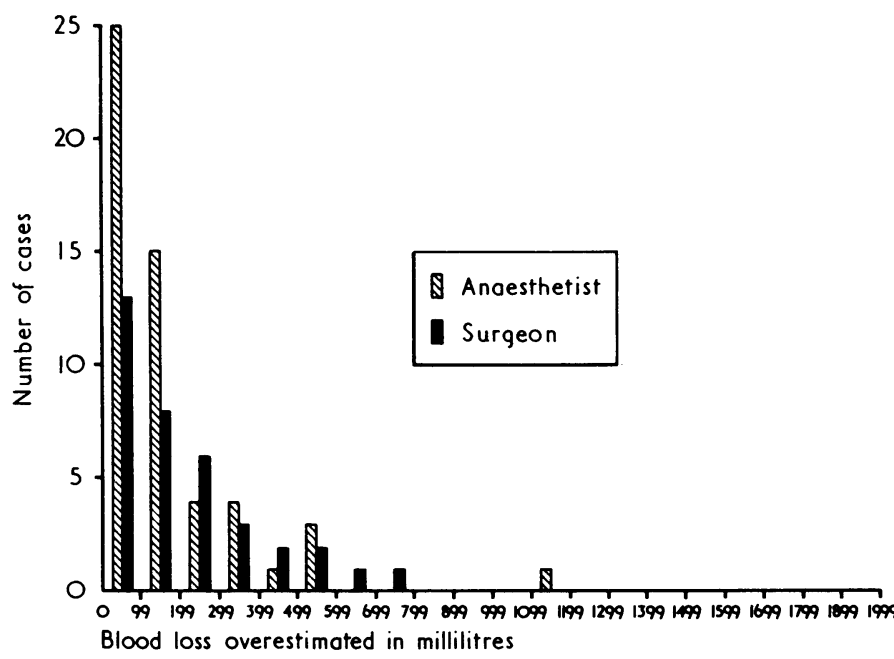

FIG. 1-Frequency of overestimation of blood loss during operation by surgeon and anaesthetist.

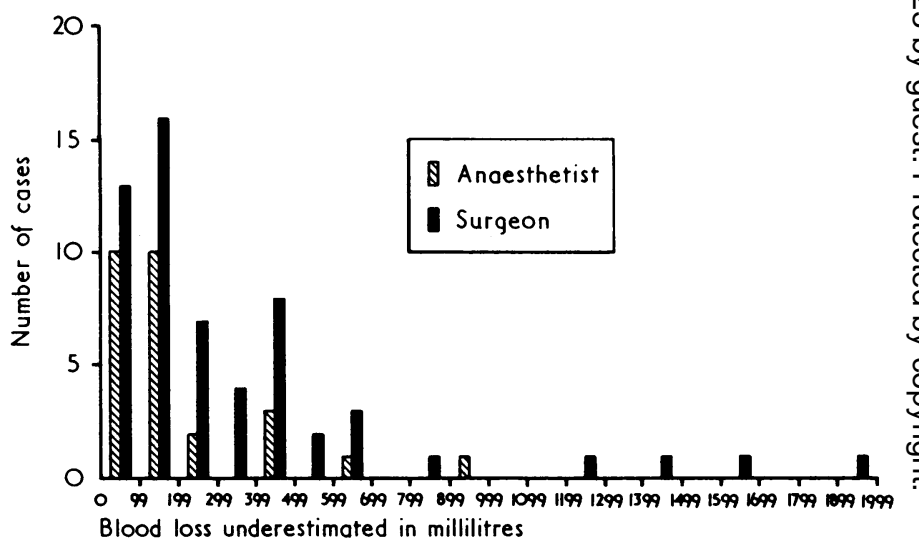

FIG. 2-Frequency of underestimation of blood loss during operation by surgeon and anaesthetist. 
The results obtained show that the anaesthetist was statistically significantly the less unreliable a judge of operative blood loss compared with the surgeon. The anaesthetist's estimate coincided with that measured by the machine 20 times; he overestimated 52 cases and underestimated 26 cases.

The frequency of overestimating blood loss by the anaesthetist and by the surgeon is shown in Fig. 1. Of the 52 times that the anaesthetist overestimated blood loss this was within the $0-99 \mathrm{ml}$ on 25 occasions.

The anaesthetist did not underestimate blood loss beyond $1,000 \mathrm{ml}$, whereas the surgeon underestimated up to $2,000 \mathrm{ml}$ (Fig. 2).

\section{Discussion and Conclusion}

Haemophobia is defined as a morbid dread of blood (Dorland's Illustrated Medical Dictionary). To the layman this morbid dread of blood often results in a faint at the sight of blood. Surgeons sometimes suffer from haemophobia in a different way; when the anaesthetist starts blood transfusion during an operation some surgeons regard it as an affront to their surgical skill and thus dislike it. Some anaesthetists have their own kind of haemophobia in that at the slightest sign of blood loss during an operation they immediately start blood transfusion.

Subjective estimation by visual assessment is extremely uncertain and should not be relied on in any but the fittest of adult patients for the simplest operations (Thornton, 1971). The method, however, has the advantage of costing nothing and of being rapid and continuous. Bonica and Lyter (1951), in summarizing the work of 17 other investigators, concluded that the blood loss estimated by the surgeon was always less than that actually measured.
Brockner and Donvig (1969) compared the amount of blood lost during operation, usually estimated by the anaesthetist and the anaesthetic nurse, with the amount of blood determined electrometrically after washing out the blood of the drapes, swabs, and sponges in 216 cases. They concluded that the visual estimation of blood loss during operation (by the anaesthetist and his nurse) was unreliable in many cases. Underestimation was more frequent than overestimation.

In situations where conditions are such that subjective estimation of blood loss is the only practical method of assessing blood loss during an operation the anaesthetist should conjointly with the surgeon make the estimate, but the anaesthetist should remember that his surgical colleague is a less reliable judge.

Thanks are due to my surgical and anaesthetic colleagues and to the anaesthetic nursing staff who took part in this study. Thanks are also due to Mr. Henry Lee and to Miss S. Dawood for the preparation of the charts and the secretarial work respectively. Mr. Lai Yeow Hin, of the medical records unit, University Hospital, gave invaluable help in the statistical analysis of the results.

\section{References}

Bonica, J. J., and Lyter, C. S. (1951). American fournal of Surgery, 81, 496. Brockner, J., and Donvig, M. (1969). Acta Anaesthesiologica Scandinavica, 13,21

Dorland's Illustrated Medical Dictionary, (1965). 24th ed., p. 664. Philadelphia, Saunders.

Endahl, I., and Moller, H. (1952). Acta Chirurgica Scandinavica, 103, 258. Gatch, W. D., and Little, W. D. (1924). Fournal of the American Medica Association, 83, 1075.

LeVeen, H. H., and Rubricius, J. L. (1958). Surgery, Gynecology and Obstetrics, 106, 368

Rustard, H. (1963). Acta Chirurgica Scandinavica, 125, 14.

Thornton, J. A. (1971). General Anaesthesia, ed. T. C. Gray, and J. F. Nunn, 3rd ed., vol. 2 , p. 511 . London, Butterworth.

Wangensteen, O. H. (1942). Minnesota Medicine, 25, 783.

Williams, J. A., and Fine, J. (1961). New England fournal of Medicine, 264, 842 .

\section{Complicated Migraine and Haemoglobin AS in Nigerians}

\section{BENJAMIN O. OSUNTOKUN, OLABOPO OSUNTOKUN}

British Medical fournal, 1972, 2, 621-622

\section{Summary}

Among 123 Nigerians with migraine seen at one clinic $49(40 \%)$ had complicated migraine, with ophthalmoplegia in 20 and amaurosis or field defects in 13. Haemoglobin AS was found in $60 \%$ of patients with complicated migraine, compared with $20 \%$ of those with simple migraine.

\section{Introduction}

Earlier reports suggested that migraine is uncommon in Africans, and that where it was frequent it seemed rather mild and seldom caused absence from work (Trowell, 1960). In University College Hospital (U.C.H.), Ibadan, the frequency of migraine in the hospital population is 3 per 10,000 (Osuntokun, 1971), which is much lower than the figure of 15 per 10,000 quoted for Caucasians (Merritt, 1967). More than transient neurological defects in the prodromal phase or during or after attack of migrainous headache are fairly uncommon in most reported

\section{University College Hospital, Ibadan, Nigeria}

BENJAMIN O. OSUNTOKUN, M.D., PH.D., M.R.C.P., Professor of Neurology

OLABOPO OSUNTOKUN, M.B., B.S., D.o., Lecturer in Ophthalmology series of patients who suffered from migraine (Merritt, 1967). We have observed a somewhat unusually high frequency of "complicated" migraine in the Nigerians. Our findings are of interest, especially with regard to the relation of such complications to haemoglobinopathy, which is common in several negroid populations.

\section{Patients and Methods}

During 1966-71 we saw 123 Nigerians who suffered from migraine or migrainous neuralgia (Horton's syndrome, cluster headaches). They were evaluated in the neurology clinic, U.C.H., Ibadan; a number of these patients were, in fact, initially seen at the ophthalmology clinic, U.C.H., Ibadan, by one of us (O.O.).

For the purpose of this paper we define "complicated migraine" as migraine with symptoms or manifestations of abnormal neuronal functions, such as amaurosis, ptosis, ophthalmoplegia, other localized weakness, sensory loss, disturbance of speech and equilibrium, or loss of consciousness, and lasting more than one hour, preceding, associated with, or following the headache of migraine.

Apart from detailed clinical, neurological, and ophthalmological assessment, investigations included plain radiographs of chest, cervical spine, and skull, and determination of haematological indices, including haemoglobin electrophoretic fractionation on Whatman's $3 \mathrm{MM}$ chromatographic paper in 